\title{
Age-related and stand-wise estimates of carbon stocks and sequestration in the aboveground coarse wood biomass of wetland forests in the northern Pantanal, Brazil
}

\author{
J. Schöngart ${ }^{1,2,3}$, J. Arieira ${ }^{3,4}$, C. Felfili Fortes ${ }^{4}$, E. Cezarine de Arruda ${ }^{3,4}$, and C. Nunes da Cunha ${ }^{3,4}$ \\ ${ }^{1}$ Max Planck Institute for Chemistry, Biogeochemistry Department, P.O. Box 3060, 55020 Mainz, Germany \\ ${ }^{2}$ Instituto Nacional de Pesquisas da Amazônia (INPA), Av. André Araújo 2936, P.O. Box 478, 69011-970 Manaus-AM, Brazil \\ ${ }^{3}$ Instituto Nacional de Ciência e Tecnologia em Áreas Úmidas (INAU), Federal University of Mato Grosso, Cuiabá-MT, \\ 78060-900, Brazil \\ ${ }^{4}$ Núcleo de Estudos Ecológicos do Pantanal (NEPA), Instituto de Biociências, Federal University of Mato Grosso, \\ Cuiabá-MT, 78060-900, Brazil
}

Received: 20 February 2008 - Published in Biogeosciences Discuss.: 20 May 2008

Revised: 26 October 2011 - Accepted: 30 October 2011 - Published: 28 November 2011

\begin{abstract}
In this study we use allometric models combined with tree ring analysis to estimate carbon stocks and sequestration in the aboveground coarse wood biomass (AGWB) of wetland forests in the Pantanal, located in central South America. In four 1-ha plots in stands characterized by the pioneer tree species Vochysia divergens Pohl (Vochysiaceae) forest inventories (trees $\geq 10 \mathrm{~cm}$ diameter at breast height, $D$ ) have been performed and converted to estimates of AGWB by two allometric models using three independent parameters $(D$, tree height $H$ and wood density $\rho)$. We perform a propagation of measurement errors to estimate uncertainties in the estimates of AGWB. Carbon stocks of AGWB vary from $7.8 \pm 1.5$ to $97.2 \pm 14.4 \mathrm{Mg} \mathrm{C} \mathrm{ha}^{-1}$ between the four stands. From models relating tree ages determined by dendrochronological techniques to $\mathrm{C}$-stocks in AGWB we derived estimates for $\mathrm{C}$-sequestration which differs from $0.50 \pm 0.03$ to $3.34 \pm 0.31 \mathrm{MgC} \mathrm{ha}^{-1} \mathrm{yr}^{-1}$. Maps based on geostatistic techniques indicate the heterogeneous spatial distribution of tree ages and C-stocks of the four studied stands. This distribution is the result of forest dynamics due to the colonizing and retreating of $V$. divergens and other species associated with pluriannual wet and dry episodes in the Pantanal, respectively. Such information is essential for the management of the cultural landscape of the Pantanal wetlands.
\end{abstract}

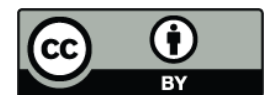

Correspondence to: J. Schöngart (j.schoengart@mpic.de)

\section{Introduction}

The aboveground coarse wood biomass (AGWB) of tropical forests is a dynamic carbon pool and plays an important role in the global carbon cycle (Malhi et al., 2004). In areas undergoing deforestation AGWB is also a source of carbon emission to the atmosphere (Houghton et al., 2000). Deforestation, especially in tropical countries, contributes substantially to increasing greenhouse gas concentrations in the atmosphere (IPCC, 2007). In this context the United Nations collaborative initiative on reducing emissions from deforestation and forest degradation (REDD) in developing countries is an effort to mitigate global warming. The REDD+ goes beyond deforestation and forest degradation, and includes the role of conservation, sustainable management of intact forests and enhancement of forest carbon stocks to create a monetary value for carbon stored in forests. But uncertainties still remain in the absolute magnitude of AGWB and carbon sequestration in different tropical forest ecosystems. There is also controversial discussion over how the carbon pools will react to changing environmental factors such as increased $\mathrm{CO}_{2}$ concentrations in the atmosphere and shifting patterns in precipitation (Ometto et al., 2005; Lloyd et al., 2007) driven by large-scale climate variations such as sea surface temperature (SST) anomalies in the tropical ocean sectors.

Generally C-sequestration in the AGWB of tropical forests is estimated by repeated diameter measurements from different censuses in permanent sample plots, as for instance, within the RAINFOR program (Amazon Forest Inventory

Published by Copernicus Publications on behalf of the European Geosciences Union. 
Network) (Peacock et al., 2007). However, repeated diameter measurements often present problems of a different nature such as buttresses and other bole deformations which can cause errors in the determination of diameter increment rates (Chave et al., 2004). Other well-known problems are "negative" diameter increment rates between two censuses which by definition do not exist, save as the result of bark shedding or dehydration causing a shrinking of bark and sapwood. Tree ring analysis (dendrochronology) produces annual diameter increments by retrospective analysis over the whole lifespan of a tree. In this study we estimate the changes in AGWB using tree rings which are annually formed in the wood of Pantanal's tree species as a consequence of seasonal rainfall (Ishii, 1998; Mattos, 1999; Arruda, 2006; Fortes, 2006) in combination with two allometric models.

The Pantanal is one of the largest wetlands in the world, but increases in deforestation for the establishment of cultivated pastures and agriculture lands endanger its ecosystems (Silva et al., 1999; Seidl et al., 2001). Rivers periodically flood the Pantanal as a result of the seasonal precipitation regime in their watersheds (Nunes da Cunha and Junk, 2004). Wetland forests in the Pantanal establish at elevations up to $3 \mathrm{~m}$ above the mean water level and consist of different species compositions depending on the flood and drought tolerance of the tree species and soil conditions (Nunes da Cunha and Junk, 2001, 2004; Ariera et al., 2011). The different forest types cover $30 \%$ of the total area and have crucial functions in this unique wetland ecosystem as habitats for a large number of plant and animal species, and as biogeochemical sinks and sources (Silva et al., 1999; Nunes da Cunha et al., 2004). However, their function in the biogeochemical cycle as C-stockers and C-sequesters is unknown. Such data are fundamental to develop plans for conservation and sustainable management of natural resources and cultural landscapes. Estimations of AGWB for forests in the Pantanal so far are based on estimations for single tree species (Haase and Haase, 1995; Salis et al., 2006). Despite the fact that former studies in the Pantanal have contributed substantially in developing allometric equations for biomass estimations, they do not provide estimations for Cstocks in AGWB and the forest's productivity in terms of $\mathrm{C}$-sequestration.

In this study we analyze the structure of four stands with a high abundance of the pioneer species Vochysia divergens Pohl (Vochysiaceae) (Brazilian name: "cambará") and other associated tree species in the understory. We estimate Cstocks of the AGWB using two allometric models with three independent predictors. We determine tree ages and diameter increment rates of $V$. divergens and other species by tree-ring analyses. Combining the changes in the C-stock of AGWB using the current diameter increment rates provides an estimate of the annual C-sequestration rates in AGWB. Using geostatistical techniques we illustrate the spatial distribution of tree ages and C-stocks and discuss forest dynamics related to the occurrence of wet and dry episodes.

\section{Material and methods}

\subsection{Study area}

The field study was carried out in the northern Pantanal of the Brazilian state Mato Grosso located in the center of South America $\left(16-22^{\circ} \mathrm{S} ; 55-58^{\circ} \mathrm{W}\right)$ (Fig. 1). The study site is the SESC Pantanal Ecological Station located in the vicinity of the northern limit of the Particular Reserve of Natural Patrimony (PRNP), close to the Cuiabá River (Arieira and Nunes da Cunha, 2006). Mean annual rainfall in the region varies between $1100-1200 \mathrm{~mm}$ and shows a distinct seasonality as a result of the rainy season from October to April and the dry season from May to September with mean temperatures of 23 and $26^{\circ} \mathrm{C}$ in the rainy and dry seasons, respectively (Hasenack et al., 2003). The flood pattern in the northern Pantanal is strongly influenced by the local precipitation and maximum flood levels occur during January and February, synchronously with the rainy season (Nunes da Cunha and Junk, 2001, 2004).

About $32 \%$ of the forest cover in the northern Pantanal is monodominant forest characterized by the tree species $V$. divergens, a light demanding, flood adapted pioneer tree species reaching up to $25 \mathrm{~m}$ in height and more than $80 \mathrm{~cm}$ in diameter (Nunes da Cunha and Junk, 2004; Lorenzi, 2002; Ariera et al., 2011). This species invades open areas of the Pantanal developing almost monospecific stands, locally called "cambarazal" (Pott, 1982; Nunes da Cunha and Junk, 2004; Arieira and Nunes da Cunha, 2006) with preference for medium and long-term flooded sites with a flood duration between two to four months (Arieira et al., 2011). Vochysia is brevi-deciduous remaining leafless for a short period (Schöngart et al., 2002) after shedding its leaves between April and July at the beginning of the dry season (Nunes da Cunha and Junk, 2004), which results in the formation of annual tree rings (Ishii, 1998; Fortes, 2006). This allows the application of tree ring analysis to determine ages and diameter increment rates for this and also many other associated tree species in Pantanal's wetland forests (Ishii, 1998; Mattos, 1999; Arruda, 2006; Fortes, 2006). Tree growth and colonization of $V$. divergens and other tree species is sensitive to interannual rainfall variability (Mattos, 1999; Fortes, 2006) and consequently this species responds to decadal rainfall variability by invading open areas during wet episodes and retreating during dry episodes such as in the beginning of the 1960s (Nunes da Cunha and Junk, 2004), thus creating a patchwork of different successional stages. The tree species has relatively high diameter increment rates of about $7 \mathrm{~mm} \mathrm{yr}^{-1}$ at stand ages of 25-66 yr in the southern Pantanal (Ishii, 1998). The Vochysia stands stock on gley soils characterized by a bluish-gray color resulting from iron reduction (Fortunatti and Couto, 2004). 


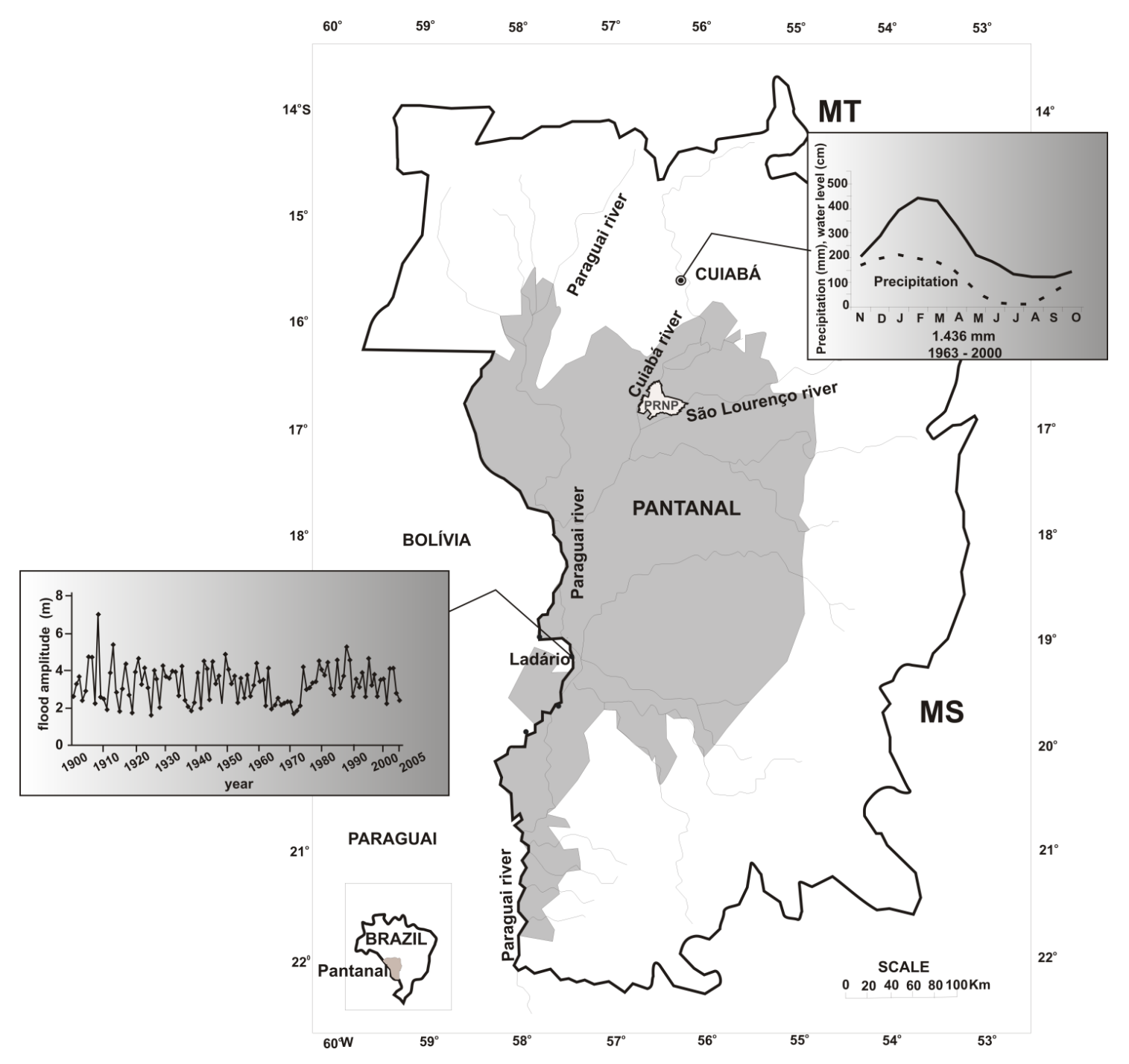

Fig. 1. Overview of the study site in N-Pantanal (SESC Pantanal Ecological Station) of Brazil. The inset figures indicate the seasonality in rainfall (city of Cuiabá) and water level fluctuations (Cuiabá River) as well as the interannual variation of the amplitude of the Paraguay River at the hydrological station in Ladário (data: ANA/GEF/PNUMA/OEA).

\subsection{Field measurements}

Four 1-ha plots were established in stands containing $V . d i$ vergens, in different positions along the flood gradient (Arieira and Nunes da Cunha, 2006) which are annually inundated by an average water column of $0.72-1.79 \mathrm{~m}$ (Table 1). Each plot was divided into 100 quadratic units of $10 \times 10 \mathrm{~m}$. The stands represent different successional stages with different population structures of $V$. divergens as the result of the variability in hydro-geomorphologic conditions but also land use history (Nunes da Cunha and Junk, 2004; Arieira and Nunes da Cunha, 2006). In all plots we measured diameter at breast height $(D) 130 \mathrm{~cm}$ above the ground with a diameter tape. From 75-91\% of all individuals in the stands, total tree height $(H)$ was measured with a Blume Leiss BL 6
(Zeiss, Jena). Sterile and fertile botanical material was collected from the tree species and identified in the Herbarium of the Federal University of Mato Grosso (UFMT).

\subsection{Estimation of C-stocks in AGWB}

The application of the appropriate allometric equation for biomass estimations is of crucial importance for reducing errors (Ketterings et al., 2001; Chave et al., 2004). Estimations of AGWB in the Pantanal have been performed by species-specific allometric models using $D$ alone as the predictor (Haase and Haase, 1995; Salis et al., 2006). However, such models have error biases, if they are applied to estimate the AGWB of forest composed by other tree species, because they have considerably varying tree heights, wood densities, 
Table 1. Stand parameters of trees $\geq 10 \mathrm{~cm} D$ in four 1-ha stands in the Pantanal (s.d.: standard deviation). Numbers in brackets indicate relative numbers for $V$. divergens.

\begin{tabular}{|c|c|c|c|c|c|}
\hline Parameter & Unit & Stand 1 & Stand 4 & Stand 2 & Stand 3 \\
\hline Mean flood height & $\mathrm{m}$ & $0.72 \pm 0.28$ & $1.13 \pm 0.16$ & $1.46 \pm 0.27$ & $1.79 \pm 0.15$ \\
\hline Tree density & trees $\mathrm{ha}^{-1}$ & $126(4.0 \%)$ & $446(84.3 \%)$ & $251(47.0 \%)$ & $256(54.3 \%)$ \\
\hline Tree species & spp. ha ${ }^{-1}$ & 22 & 12 & 9 & 15 \\
\hline Mean $D \pm$ s.d. & $\mathrm{cm}$ & $18.8 \pm 7.6$ & $36.1 \pm 11.4$ & $32.0 \pm 15.7$ & $38.3 \pm 20.0$ \\
\hline Range of $D$ & $\mathrm{~cm}$ & $10.2-43.0$ & $10.2-73.8$ & $10.5-78.9$ & $10.2-88.2$ \\
\hline Mean $H \pm$ s.d. & $\mathrm{m}$ & $8.0 \pm 3.1$ & $15.8 \pm 6.7$ & $16.6 \pm 6.5$ & $17.0 \pm 6.5$ \\
\hline Range of $H$ & $\mathrm{~m}$ & $2.1-17.2$ & $1.7-25.9$ & $2.3-29.0$ & $3.0-28.8$ \\
\hline Basal area & $\mathrm{m}^{2} \mathrm{ha}^{-1}$ & $4.1(7.3 \%)$ & $28.3(91.0 \%)$ & $25.1(79.4 \%)$ & $37.5(86.6 \%)$ \\
\hline
\end{tabular}

Table 2. Wood density $\rho$ and mean diameter increment (MDI) rates of characteristic tree species in the Pantanal (Arruda, 2006).

\begin{tabular}{lrrr}
\hline Tree species & $\mathrm{N}(\rho / \mathrm{MDI})$ & $\rho\left(\mathrm{g} \mathrm{cm}^{-3}\right)$ & $\mathrm{MDI}(\mathrm{mm})$ \\
\hline Albizia polyantha (Spreng. F.) Lewis (Fabaceae) & $0 / 4$ & - & $5.4 \pm 1.5$ \\
Alchornea discolor Poepp. (Euphorbiaceae) & $2 / 3$ & $0.34 \pm 0.04$ & $7.7 \pm 6.5$ \\
Byrsonima orbignyana A. Juss. (Malpighiaceae) & $2 / 3$ & $0.47 \pm 0.01$ & $5.0 \pm 1.7$ \\
Cecropia pachystachya Trécul (Urticaceae) & $3 / 3$ & $0.30 \pm 0.07$ & $14.0 \pm 6.5$ \\
Couepia uiti (Mart. \& Zucc.) Benth. ex Hook. f. (Chrysobalanaceae) & $3 / 3$ & $0.44 \pm 0.02$ & $8.5 \pm 4.3$ \\
Coccoloba ochreolata Wedd. (Polygonaceae) & $5 / 7$ & $0.59 \pm 0.04$ & $4.4 \pm 1.2$ \\
Duroia duckei Huber (Rubiaceae) & $2 / 4$ & $0.52 \pm 0.01$ & $5.2 \pm 2.8$ \\
Garcinia brasiliensis (Mart.) Planch. \& Triana (Clusiaceae) & $2 / 0$ & $0.64 \pm 0.05$ & - \\
Mabea paniculata Spruce ex Benth. (Euphorbiaceae) & $1 / 3$ & 0.56 & $6.1 \pm 0.8$ \\
Mouriri guianensis Aubl. (Melastomataceae) & $4 / 5$ & $0.60 \pm 0.06$ & $4.5 \pm 2.0$ \\
Ocotea longifolia Kunth (Lauraceae) & $6 / 5$ & $0.47 \pm 0.05$ & $5.8 \pm 1.9$ \\
Sapium obovatum Kl. (Euphorbiaceae) & $5 / 5$ & $0.29 \pm 0.09$ & $7.2 \pm 3.2$ \\
Vochysia divergens Pohl (Vochysiaceae) & $17 / 26$ & $0.40 \pm 0.08$ & $7.9 \pm 2.8$ \\
Other species & $81 / 76$ & $0.48 \pm 0.14$ & $5.7 \pm 3.2$ \\
\hline Mean & $133 / 136$ & $0.47 \pm 0.13$ & $6.3 \pm 3.5$ \\
\hline
\end{tabular}

and crown architectures depending on the climatic, hydrologic and edaphic conditions and the stand age (successional stage) (Worbes et al., 1992; Chave et al., 2004, 2005). The species-specific allometric models of Salis et al. (2006) estimate AGWB by $D$ for tree species which do not occur in our studied stands and are thus not useful for this study. Haase and Haase (1995) develop an allometric equation for V. divergens to estimate dry weight by $D$. This model was calibrated using 14 trees with diameters from 2 to $46 \mathrm{~cm}$. However, the authors recommend not using the model for trees out of this diameter range.

An important parameter for the AGWB estimation is wood specific density $\left(\rho\right.$, in $\left.\mathrm{g} \mathrm{cm}^{-3}\right)$, which can vary considerably between tree species even in the same stand (Fearnside, 1997; Baker et al., 2004; Nogueira et al., 2005; Wittmann et al., 2006, 2008; Schöngart et al., 2010). From 48 characteristic tree species of the Pantanal comprising 130 samples (cores and stem disks), $\rho$ was calculated by the dry/fresh volume ratio after measuring the fresh volume in the field and drying the sample for $72 \mathrm{~h}$ at $105^{\circ} \mathrm{C}$ (Schöngart et al., 2005). With this data set (Arruda, 2006) we estimated $\rho$ for $67-98 \%$ of the individuals in the four stands. For another $4-31 \%$ of the individuals we used published data for the mean values and standard deviations of $\rho$ (Loureiro et al., 1979; Worbes et al., 1992; Fearnside, 1997; Ter Steege, 2001; Schöngart, 2003; Baker et al., 2004; Wittmann et al., 2006, 2008; Chave et al., 2009). For the remaining trees $(<1.6 \%$ of all individuals) we estimated $\rho$ by using the mean value of the analyzed tree species (Table 2).

Many estimates of AGWB in tropical forests are based on $D$ alone as the independent parameter (e.g. Chambers et al., 2001 ) or at least a combination of $D$ and $\rho$ (e.g. Malhi et al., 2004). Some allometric models include $H$ as an additional parameter (Brown et al., 1989; Chave et al., 2005). However, $H$ is rarely used to estimate AGWB due to difficulties of measuring this parameter in the complex vertical structure of tropical forests (Feldpausch et al., 2011). Chave et al. (2005) indicate that the most reliable estimate of C-stocks 
and consequently $\mathrm{C}$-sequestration is achieved by allometric models which use, in decreasing order of importance, $D, \rho$ and $H$ as predictors. The authors suggest that the integration of $H$ reduces the standard error of AGWB estimates by about $7 \%$. For this reason we incorporate tree height for our estimates of AGWB. Tree height was measured for $75-91 \%$ of all individuals in a stand. This was possible since the studied wetland forests do not have a complex vertical structure. To avoid errors, height was not measured from strongly inclined trees or when the visibility of the tree crown was limited. From those remaining trees we estimated height by a nonlinear regression model between $D$ (in $\mathrm{cm}$ ) and measured $H$ (in $\mathrm{m}$ ). One species-specific relationship was computed for $V$. divergens, the other species were pooled and a common second relationship was determined, both using a logarithmic equation:

$H=a+b \ln (D)$

To evaluate uncertainties due to the choice of the model (Chave et al., 2004), we selected two published allometric models which have been developed outside the biogeographic region using pan-tropical equations (Cannell, 1984; Chave et al., 2005). Both models transform $D, \rho$ and $H$ into estimates of AGWB. Cannell (1984) suggested that the AGWB of a tree corresponds to the product of the trunk basal area $\left(\mathrm{BA}=\pi D^{2} / 4\right), \rho$, total tree height $(H)$ and a constant form factor $(F=0.06)$ assuming the taper does not change as the trees become larger:

$\mathrm{AGWB}_{1}=F \cdot \rho \cdot H \cdot \pi \cdot(D / 2)^{2}$

Chave et al. (2005) developed allometric models based on a large data set from the tropics to estimate AGWB for different forest types. For forests with a distinct dry season (rainfall below $1500 \mathrm{~mm}$ per year, and a 5 month dry season), they suggested transforming forest inventory data into estimates of AGWB by the equation:

$\mathrm{AGWB}_{2}=a \cdot\left(\rho \cdot H \cdot D^{2}\right)^{b}$

The coefficients of Eq. (3) are $a=0.112$ and $b=0.916$. The units of the parameters used in Eqs. (2) and (3) were: AGWB in kilogram, $\rho$ in gram per cubic centimeter, $H$ in meter and $D$ in centimeter. Using Eqs. (2)-(3) we estimated AGWB for every tree in stands 1-4 and took the sum for the total AGWB of a stand (in Megagram $\mathrm{Mgha}^{-1}$ ).

Estimates of AGWB based on inventory data contain uncertainties such as measurement errors of $D, H$, and $\rho$, and errors caused by the choice of an allometric model and plot size (Chave et al., 2004). In this study we perform a propagation of measurement errors (Drosg, 2009) which influences the estimates of AGWB. Although the tree species in the studied stands do not have buttresses, measurement errors of $D$ frequently occur. We assume for the error propagation an uncertainty of $1 \%$ in the measured diameter and denote this error as $\sigma_{D}$. Height measurements normally are difficult to perform in the complex vertical structure of tropical forests (Feldpausch et al., 2011), although the studied wetland forests present a quite simple vertical structure and tree heights are below $30 \mathrm{~m}$. For the error propagation we assume a measurement error $\sigma_{H}$ of $10 \%$ (Chave et al., 2004). To address uncertainties in the determination of $\rho$ we use the standard deviation of species-specific $\rho$ to estimate the related error $\sigma_{\rho}$ (for those tree species without information for $\rho$ we apply the standard deviation of the mean $\rho$ from all analyzed species to estimate $\sigma_{\rho}$ ). As Eq. (2) uses a constant form factor $F$ we address an error of $10 \%$ for this parameter $\left(\sigma_{F}=0.006\right)$. The propagation of measurement errors $\sigma_{F}$, $\sigma_{D}, \sigma_{H}$ and $\sigma_{\rho}$ to estimate AGWB is performed for every single tree using the following equation:

$$
\begin{aligned}
& \sigma_{\mathrm{AGWB}(1)}^{2}=(\pi / 4)^{2} \cdot\left[\left(\sigma_{F} \cdot D^{2} \cdot H \cdot{ }_{\rho}\right)^{2}+\left(\sigma_{D} \cdot F \cdot 2 D \cdot H \cdot{ }_{\rho}\right)^{2}\right. \\
& \left.\quad+\left(\sigma_{H} \cdot F \cdot D^{2} \cdot{ }_{\rho}\right)^{2}+\left(\sigma_{\rho} \cdot F \cdot D^{2} \cdot{ }_{H}\right)^{2}\right]
\end{aligned}
$$

For Eq. (3) we apply the following equation to propagate measurement errors in the estimate for all trees:

$$
\begin{aligned}
& \sigma_{\mathrm{AGWB}(2)}^{2}=\left(a \cdot b \cdot\left(D^{2} \cdot \rho_{\rho} \cdot H\right)^{(b-1)}\right)^{2} \cdot\left[\left(\sigma_{D} \cdot H \cdot{ }_{\rho} \cdot 2 D\right)^{2}\right. \\
& \left.\quad+\left(\sigma_{H} \cdot D^{2} \cdot{ }_{\rho}\right)^{2}+\left(\sigma_{\rho} \cdot D^{2} \cdot{ }_{H}\right)^{2}\right]
\end{aligned}
$$

We calculated the relative contribution of each error in Eqs. (4) and (5) in form of percentages differentiating between trees of V. divergens and other species. We then calculate separately for each model, the sum of these errors which results by simple addition of variances:

$$
\begin{aligned}
& \sigma_{\mathrm{AGWB}(1)}=\left(\Sigma\left(\sigma_{\mathrm{AGWB}(1)}^{2}\right)\right)^{0.5} \text { and } \sigma_{\mathrm{AGWB}(2)} \\
& \quad=\left(\Sigma\left(\sigma_{\mathrm{AGWB}(2)}^{2}\right)\right)^{0.5}
\end{aligned}
$$

In the next step we calculate the mean AGWB and the new variance from Eqs. (2)-(3) to consider errors due to the choice of an allometric model:

$\sigma_{\mathrm{AGWB}(\text { mean })}^{2}=\left(\sigma_{\mathrm{AGWB}(1)}^{2}+\sigma_{\mathrm{AGWB}(2)}^{2}\right) \cdot 0.25$

Commonly carbon content is estimated as being $50 \%$ of the AGWB (Clark et al., 2001; Malhi et al., 2004). Elias and Potvin (2003) determined from 32 tropical tree species of Central Panama a lower wood carbon content ranging from 44.4 to $49.4 \%$. They found a strong relationship between $\rho$ and $\mathrm{C}$-content from different tree species. We assume that C-content of AGWB from Pantanal's wetland forests also correlates with $\rho$ and transform the linear regression model of Elias and Potvin (2003) to estimate C-content using $\rho$ $\left(\mathrm{g} \mathrm{cm}^{-3}\right)$ for the wetland tree species using the following equation:

$\mathrm{C}(\%)=(\rho+16.21) / 0.3732$

Multiplying the C-content with AGWB produces an estimate for its $\mathrm{C}$-stock and takes into consideration the variances. 


\subsection{Tree ring analysis and estimation of $\mathrm{C}$-sequestration in AGWB}

In the surroundings of the PRNP stem disks were collected with a chainsaw at $130 \mathrm{~cm}$ height between $\mathrm{Au}-$ gust 2004 and September 2005. The samples included 26 trees of $V$. divergens (Fortes, 2006) and 108 trees of 57 other common wetland tree species (Arruda, 2006). The wood samples were analyzed in the dendroecological laboratory at the National Institute for Amazon Research (INPA) in Manaus, using standard dendrochronological procedures (Pilcher, 1990). Samples were progressively sanded to analyze the tree ring structure macroscopically by wood anatomical features characterized by density variations (e.g. Annonaceae, Lauraceae, Myrtaceae), marginal parenchyma bands (e.g. Fabaceae sensu lato), alternating fiber and parenchyma tissues (e.g. Sapotaceae, Moraceae, Lecythidaceae) or rarely, by variations in the vessel size and distribution (Worbes, 2002). Ring width was measured for trees from $V$. divergens to the nearest $0.01 \mathrm{~mm}$ using a digital measuring device (LINTAB, RINNTECH, Inc.) supported by the software TSAP (Time Series Analyses and Presentation).

Tree age, determined by ring counting, was related to $D$ to produce one model for $V$. divergens and a second model for the other associated tree species fitting the age-diameter relationship to a non-linear (sigmoidal) regression (Schöngart et al., 2007, 2010):

$D=a /\left(1+b \cdot \mathrm{age}^{-c}\right)$

From these two models we derived the current (annual) diameter increment (CDI, in $\mathrm{cm}$ ) for $V$. divergens and other tree species as being the difference in $D$ from year to year $(t)$ by the following equation:

$\mathrm{CDI}=D_{(t)}-D_{(t-1)}$

We relate tree age from those trees analyzed by dendrochronological methods to their estimated C-stocks in AGWB (considering the propagation of measurement errors) using a sigmoidal regression model. One model is produced for $V$. divergens; the other tree species are pooled to produce a second model:

C-stock $=a /\left(1+b \cdot \mathrm{age}^{-c}\right)$

From these regression models we derive $\mathrm{C}$-sequestration in AGWB ( $\left.\mathrm{kg} \mathrm{C} \mathrm{yr}^{-1}\right)$ for $V$. divergens and for other tree species calculating the difference of the $\mathrm{C}$-stock between consecutive years $(t)$ along the whole life span:

C-sequestration $=\mathrm{C}$-stock $(t)-\mathrm{C}$ - $\operatorname{stock}_{(t-1)}$

Based on a total of 134 trees with determined ages, we develop a linear multiple regression model to predict age by $D$ (cm) and $\rho\left(\mathrm{g} \mathrm{cm}^{-3}\right)$ :

Age $=a+b \cdot D+c \cdot \rho$
Using Eq. (13) we estimate for all individuals in stands 14 tree age. To estimate $\mathrm{C}$-sequestration we calculate in the next step the differences in C-stock of AGWB for the year of stand inventory $(t)$ and the year before $(t-1)$ using Eqs. (2) and (3). To do that, we subtracted the CDI from $D$ and then reduced $H$ by the specific diameter-height relationship of Eq. (1). The variance of C-sequestration of a tree is estimated by the difference of the variances from the C-stocks in AGWB calculated using Eqs. (4) and (5) as well as a mean value calculated using Eq. (7). The sum of the individual variances yields an estimate for the uncertainties in the Csequestration of a stand.

Growth modeling was performed with the software program X-Act 7.0 (SciLab) and Statistica 6.0.

\subsection{Mapping C-stocks and tree age}

Maps for the spatial distribution of ages and carbon stocks from all trees in each stand were produced using two geostatistic techniques: (1) variogram analysis and (2) simple kriging (Arieira et al., 2011). Variogram analysis was applied to derive information on the spatial data structure (Wagner and Fortin, 2005). Kriging is a spatial interpolation technique for producing estimates at unobserved locations by a weighted average of nearby samples (Miller et al., 2007). Sample variograms were estimated and variogram models fitted to the 100 quadratic units of each 1-ha plot. Different variogram models (spherical, Gaussian, and exponential) were tested and the most reliable model was chosen based on the best adjustment between observed and predicted data evaluated by cross-validation. The ratio of nugget $(\mathrm{Co})$ variance to total variance $(\mathrm{Co}+\mathrm{C})$ was calculated for each variogram to evaluate which proportion of the variance resulted from spatially structured variance and random factors. Considering the spatial correlation of data provided by the variograms, kriging was performed resulting in grid maps with cell size of $0.4 \times 0.4 \mathrm{~m}$. We applied variogram analysis and kriging using Gama Design Software, version 3.1.7. The resulting kriged maps were edited in Surfer Software, version 7.0.

\section{Results}

Tree density in the four studied stands varied between 126446 individuals $\mathrm{ha}^{-1}$ comprising 9-22 tree species $\mathrm{ha}^{-1}$ $(\geq 10 \mathrm{~cm} \mathrm{D}$ ) (Table 1). The relative abundance of $V$. divergens differed considerably between the studied stands ranging from $4 \%$ (stand 1), $47 \%$ (stand 2), $54 \%$ (stand 3 ) to $84 \%$ (stand 4 ). Mean $D$ was $18.8 \mathrm{~cm}$ in stand 1 , the other three stands had a much higher average $D$ between 32.0 and $38.3 \mathrm{~cm}$. The mean $H(8.0 \mathrm{~m})$ in stand 1 was two times lower than in the stands 2-4 $(15.8-17.0 \mathrm{~m})$. Basal area varied between $4.1 \mathrm{~m}^{2} \mathrm{ha}^{-1}$ in stand 1 and $37.5 \mathrm{~m}^{2} \mathrm{ha}^{-1}$ in stand 3 . Due to the high relative abundance of $V$. divergens in stands $2-4$, this species comprised $79-91 \%$ of the stand's basal 

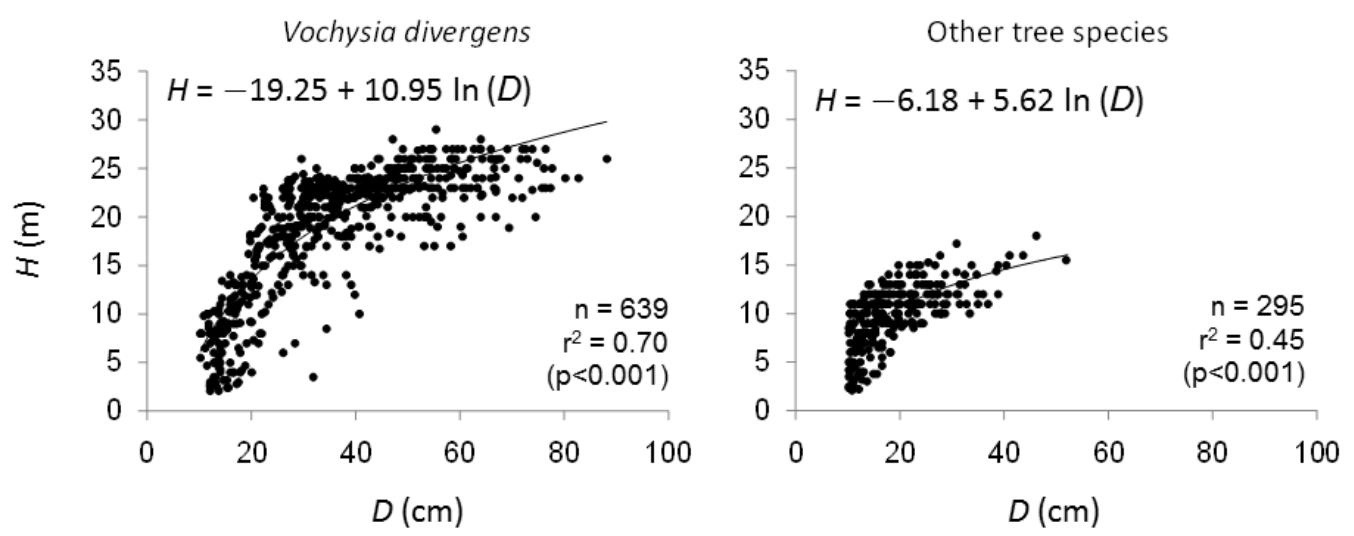

Fig. 2. Non-linear relationships between diameter at breast height, $D$, and tree height, $H$, from Vochysia divergens and other tree species from northern Pantanal wetland forests.

area, while in stand $1 \mathrm{~V}$. divergens only achieved $7 \%$ of the total basal area. $V$. divergens had a relatively low $\rho$ of $0.40 \pm 0.08 \mathrm{~g} \mathrm{~cm}^{-3}$ (Table 2). Mean diameter increment rate (MDI), calculated by the ratio $D$ and tree age determined by tree ring analysis (Arruda, 2006; Fortes, 2006), was $7.9 \pm 2.8 \mathrm{~mm} \mathrm{yr}^{-1}$ for $V$. divergens. The MDI of all species was $6.3 \pm 3.5 \mathrm{~mm} \mathrm{yr}^{-1}$ (Table 2). Wood density and MDIs were inversely correlated $(n=105 ; r=-0.44 ; p<0.001)$.

To estimate the AGWB, we applied Eqs. (2)-(3) using $D, \rho$ and $H$ as independent variables (predictors). For those trees with missing tree heights we estimated $H$ by the specific diameter-height relationship of Eq. (1), explaining between $70 \%$ ( $V$. divergens) and $45 \%$ (other tree species) of the variability between the two parameters (Fig. 2). Equations (2)-(3) yielded for the same stand similar estimates for AGWB (Table 3). The mean value of AGWB calculated by Eqs. (2) and (3) indicated the lowest $\mathrm{AGWB}$ of $17.4 \pm 3.3 \mathrm{Mgha}^{-1}$ for stand 1 . For stands 4 and 2 estimated AGWB was similar with $137.3 \pm 19.7 \mathrm{Mgha}^{-1}$ and $136.3 \pm 19.8 \mathrm{Mgha}^{-1}$, respectively. The highest AGWB was predicted for stand 3 with $218.1 \pm 32.2 \mathrm{Mg} \mathrm{ha}^{-1}$. Estimates for the C-content of AGWB by applying Eq. (7) varied from 44.6 to $44.9 \%$ and yielded C-stocks of $7.8 \pm 1.5 \mathrm{MgCha}^{-1}$ (stand 1), $63.3 \pm 8.8 \mathrm{MgCha}^{-1}$ (stand 4 ), $\quad 60.8 \pm 8.8 \mathrm{MgCha}^{-1}$ (stand 2) and 97.2 $\pm 14.4 \mathrm{Mg} \mathrm{Cha}^{-1}$ (stand 3).

The propagation of measurement errors in the prediction of AGWB was higher for the estimates calculated with Eq. (2) compared to Eq. (3) (Table 4). The uncertainties in the estimate of AGWB for $V$. divergens were $20.8 \%$ in Eq. (2) and $16.7 \%$ in Eq. (3). For the other species the calculated measurement errors were $19.2 \pm 6.2 \%$ in Eq. (2) and $14.7 \pm 6.4 \%$ in Eq. (3). Calculating the mean value of AGWB from Eqs. (2)-(3) reduced the uncertainties to $10.9 \pm 2.0 \%$ for $V$. divergens and $10.6 \pm 5.1 \%$ for other tree species. The uncertainties in the estimate of AGWB for $V$. divergens applying Eq. (2) was $52.8 \%$ from $\sigma_{\rho}$, while $\sigma_{F}$ and $\sigma_{H}$ shared equally with $23.1 \%$ to the variance. The contribution of $\sigma_{H}$ and $\sigma_{\rho}$ to the variance of Eq. (3) was $30.1 \%$ and $68.7 \%$ for $V$. divergens, respectively (Table 4 ). For the estimate of AGWB for the other tree species, applying Eq. (2), $\sigma_{\rho}$ contributed with $31.4 \pm 30.2 \%$ (s.d.) to the variance, while $33.6 \pm 14.8 \%$ was explained by $\sigma_{F}$ and $\sigma_{H}$. The variance for the estimates of AGWB using Eq. (3) was shared by $\sigma_{H}(58.2 \pm 34.1 \%)$ and $\sigma_{\rho}(39.5 \pm 35.5 \%)$. If no information for $\rho$ was available for a tree $(<1.6 \%$ of all individuals), $\sigma_{\rho}$ became a major source of error contributing up to $90 \%$ to uncertainties in AGWB estimates. Uncertainties regarding the diameter measurements (assuming a measurement error of $1 \%$ ) were negligible in Eqs. (2) and (3).

Tree age and $D$ of $V$. divergens $\left(n=26 ; r^{2}=0.94 ; p<\right.$ $0.0001)$ and other tree species $\left(n=108 ; r^{2}=0.74, p<\right.$ 0.0001) correlated significantly (Fig. 3). We also found a close relationship between age and accumulated C-stock in AGWB of $V$. divergens and other tree species (Fig. 4). Maximum $C$-sequestration in AGWB of $V$. divergens occurred at an age of $80 \mathrm{yr}$, and for the other tree species at an age of 76 yr. The pioneer species $V$. divergens had higher productivity than the other associated tree species from the understory which can be traced back to lower irradiance in the subcanopy. Based on the significant relationships between $\rho$ and MDI as well as tree age and $D$ we developed a multiple regression model that accurately predicted tree age by wood density and $D$ as independent parameters $\left(n=117 ; r^{2}=\right.$ 0.93; $p<0.0001$ ) (Fig. 5). Partial regression analysis indicated that $D(\beta=0.921 ; t=26.68 ; p<0.0001)$ contributed more than $\rho(\beta=0.184 ; t=5.33 ; p<0.0001)$ to explain the variability of tree age. By Eq. (13) we calculated tree ages in stands 1-4 and estimated (minimum) stand age by the maximum tree age of a stand (Worbes et al., 1992) which varied from $64 \mathrm{yr}$ (stand 1) to $124 \mathrm{yr}$ (stand 3). In the next step we calculated the difference between the C-stocks in AGWB for the year of forest inventory and the year before to estimate annual C-sequestration in AGWB (Table 3). Models (2) 
Table 3. Estimated AGWB, Carbon stocks and C-sequestration projected by allometric Eqs. (2)-(3) in four stands of wetland forests in the Northern Pantanal. The propagation of measurement errors is indicated by standard errors.

\begin{tabular}{|c|c|c|c|c|}
\hline & Stand 1 & Stand 4 & Stand 2 & Stand 3 \\
\hline Stand age (years) & 64 & 99 & 108 & 124 \\
\hline & \multicolumn{4}{|c|}{$\left(\mathrm{Mg} \mathrm{ha}^{-1}\right)$} \\
\hline \multicolumn{5}{|l|}{ Eq. (2) } \\
\hline $\mathrm{AGWB}_{1}$ & 15.9 & 131.0 & 133.6 & 218.1 \\
\hline$\sigma_{\mathrm{AGWB}_{1}}$ & 4.1 & 25.5 & 26.1 & 42.9 \\
\hline \multicolumn{5}{|l|}{ Eq. (3) } \\
\hline $\mathrm{AGWB}_{2}$ & 18.8 & 143.3 & 139.1 & 218.1 \\
\hline$\sigma_{\mathrm{AGWB}_{2}}$ & 3.9 & 22.4 & 21.6 & 34.1 \\
\hline \multicolumn{5}{|l|}{ Mean of Eqs. (2)-(3) } \\
\hline $\mathrm{AGWB}_{\text {mean }}$ & 17.4 & 137.3 & 136.3 & 218.1 \\
\hline$\sigma_{\mathrm{AGWB}_{\text {mean }}}$ & 3.3 & 19.7 & 19.8 & 32.2 \\
\hline & \multicolumn{4}{|c|}{$\left(\mathrm{MgCha}^{-1}\right)$} \\
\hline \multicolumn{5}{|l|}{ Eq. (2) } \\
\hline C-stock $\left(\mathrm{AGWB}_{1}\right)$ & 7.2 & 58.3 & 59.6 & 97.2 \\
\hline$\sigma_{\mathrm{C} \text {-stock }}$ & 1.9 & 11.4 & 11.7 & 19.1 \\
\hline \multicolumn{5}{|l|}{ Eq. (3) } \\
\hline C-stock $\left(\mathrm{AGWB}_{2}\right)$ & 8.5 & 68.3 & 62.0 & 97.2 \\
\hline$\sigma_{\mathrm{C} \text {-stock }}$ & 1.7 & 10.0 & 9.6 & 15.2 \\
\hline \multicolumn{5}{|l|}{ Mean of Eqs. (2)-(3) } \\
\hline C-stock $\left(\mathrm{AGWB}_{\text {mean }}\right)$ & 7.8 & 63.3 & 60.8 & 97.2 \\
\hline \multirow[t]{2}{*}{$\sigma_{\mathrm{C} \text {-stock }}$} & 1.5 & 8.8 & 8.8 & 14.4 \\
\hline & \multicolumn{4}{|c|}{$\left(\mathrm{MgCha}^{-1} \mathrm{yr}^{-1}\right)$} \\
\hline \multicolumn{5}{|l|}{ Eq. (2) } \\
\hline $\mathrm{C}$-sequestration $\left(\mathrm{AGWB}_{1}\right)$ & 0.47 & 3.27 & 2.31 & 2.96 \\
\hline$\sigma_{\mathrm{C} \text {-sequestration }}$ & 0.01 & 0.67 & 0.46 & 0.63 \\
\hline \multicolumn{5}{|l|}{ Eq. (3) } \\
\hline C-sequestration $\left(\mathrm{AGWB}_{2}\right)$ & 0.52 & 3.42 & 2.27 & 2.80 \\
\hline$\sigma_{\mathrm{C} \text {-sequestration }}$ & 0.11 & 0.56 & 0.36 & 0.49 \\
\hline \multicolumn{5}{|l|}{ Mean of Eqs. (2)-(3) } \\
\hline $\mathrm{C}$-sequestration $\left(\mathrm{AGWB}_{\text {mean }}\right)$ & 0.50 & 3.34 & 2.29 & 2.88 \\
\hline$\sigma_{\mathrm{C} \text {-sequestration }}$ & 0.03 & 0.31 & 0.21 & 0.28 \\
\hline
\end{tabular}

and (3) indicated almost the same C-sequestration in the four studied stands. The lowest estimated mean $\mathrm{C}$-sequestration in AGWB is $0.50 \pm 0.03 \mathrm{MgCha}^{-1} \mathrm{yr}^{-1}$ in the 64-yr old stand 1, while stand 4 (99 yr old) presented the highest Csequestration with $3.34 \pm 0.31 \mathrm{MgC} \mathrm{ha}^{-1} \mathrm{yr}^{-1}$. For stands 2 (108 yr old) and 3 (124 yr old) the models estimated a mean C-sequestration of $2.29 \pm 0.21 \mathrm{MgC} \mathrm{ha}^{-1} \mathrm{yr}^{-1}$ and $2.88 \pm 0.28 \mathrm{MgC} \mathrm{ha}^{-1} \mathrm{yr}^{-1}$, respectively.
Table 4. Propagation of assumed measurement errors for converting forest inventory data $(D, H, \rho, F)$ into estimates of AGWB using Eqs. (2) and (3) differentiated for trees of $V$. divergens and other species.

\begin{tabular}{lrr}
\hline Vochysia divergens & Eq. (2) $\left(\mathrm{AGWB}_{1}\right)$ & Eq. (3) $\left(\mathrm{AGWB}_{2}\right)$ \\
\hline Total error in & $20.8 \%$ & $16.7 \%$ \\
AGWB estimate & & \\
\hline$\sigma_{\rho}$ & $52.8 \%$ & $30.1 \%$ \\
$\sigma_{H}$ & $23.1 \%$ & $68.7 \%$ \\
$\sigma_{D}$ & $1.0 \%$ & $1.2 \%$ \\
$\sigma_{F}$ & $23.1 \%$ & - \\
\hline Other tree species & Eq. $(2)\left(\mathrm{AGWB}_{1}\right)$ & Eq. (3) $\left(\mathrm{AGWB}_{2}\right)$ \\
\hline Total error in & $19.2 \pm 6.2 \%$ & $14.7 \pm 6.4 \%$ \\
AGWB estimate & & \\
\hline$\sigma_{\rho}$ & $31.4 \pm 30.2 \%$ & $39.5 \pm 35.5 \%$ \\
$\sigma_{H}$ & $33.6 \pm 14.8 \%$ & $58.2 \pm 34.1 \%$ \\
$\sigma_{D}$ & $1.3 \pm 0.6 \%$ & $2.3 \pm 1.4 \%$ \\
$\sigma_{F}$ & $33.6 \pm 14.8 \%$ & - \\
\hline
\end{tabular}

Age structure of the stands indicated that the majority of trees $(D>10 \mathrm{~cm})$ were between 20 and $40 \mathrm{yr}$ old. In the chronosequence of stands, the number of $V$. divergens individuals increased towards higher age classes (Fig. 6a). The range of spatial dependence varied mainly between the youngest stand (stand 1, from 62.1 to $85.2 \mathrm{~m}$ ) and the older ones (stand 2, 4, 3; from 26.8 to $59.1 \mathrm{~m}$ ) (Table 5). Variogram analysis showed that the majority of the spatial heterogeneity of tree age and C-stock results from spatial dependent ecological processes, such as dispersion. Only a small portion of the variance of these two variables might be explained by random factors, as suggested by the ratio of nugget $(\mathrm{Co})$ variance to total variance $(\mathrm{Co}+\mathrm{C})$ as seen in Table 5. Random factors might pose a greater influence on the spatial heterogeneity of tree age in the initial stages of succession, when $V$. divergens individuals were colonizing open areas. The maps in Fig. 6b show the patterns of establishment of $V$. divergens over the successional development of the forest. In all stands $V$. divergens distribution exhibited a clumpy pattern with variation of patch age. The stands presented islands of older trees and areas which had been colonized during the last $40 \mathrm{yr}$ (Fig. 6b). The distribution of C-stocks (Fig. 6c) indicated low $\mathrm{C}$-stocks in the recently colonized areas and higher C-stocks with increasing age.

\section{Discussion}

In this study we show a new approach in tropical forest research for estimating C-sequestration in AGWB by means of growth models based on tree ring analysis (Schöngart et al., 

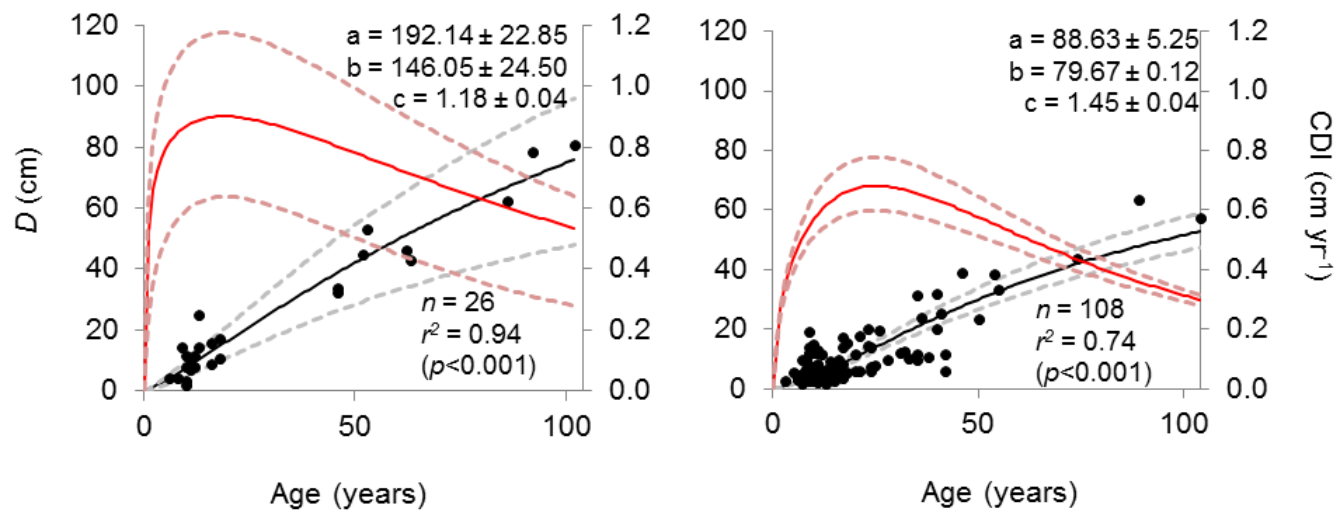

Fig. 3. Significant age-diameter relationships for $V$. divergens and other tree species. The red line indicates the annual current diameter increment (CDI). Indicated parameters are for the age-diameter relationship of Eq. (9). Standard deviation is indicated by the dotted lines.
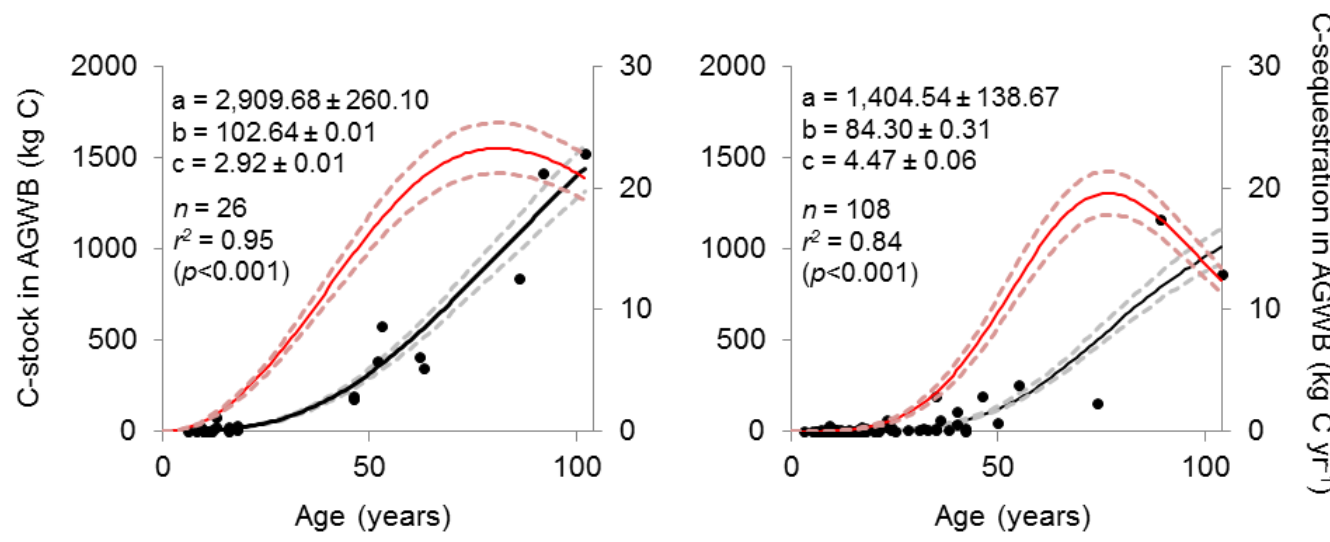

Fig. 4. C-stocks (black curve) and C-sequestration (red curve) of AGWB from Vochysia divergens and other tree species from northern Pantanal wetland forests related to tree ages. Indicated parameters are for Eq. (11). The dotted lines indicate the standard deviation.

2010). Ishii (1998) first indicated the occurrence of annual tree rings in the Pantanal using radiocarbon-dating and cambial wounding (windows of Mariaux). Mattos (1999) related ring width of Tabebuia heptaphylla successfully with precipitation patterns in the southern Pantanal. Ring width of $V$. divergens in the northern Pantanal is significantly correlated with the annual precipitation regime indicating the existence of annual tree rings for this species (Fortes, 2006). These results are congruent with many other dendrochronological studies performed in tropical regions with a seasonal precipitation regime (e.g. Jacoby and D'Arrigo, 1990; Stahle et al., 1999; Worbes, 1999; Enquist and Leffler, 2001; Fichtler et al., 2004; Brienen and Zuidema, 2005; Schöngart et al., 2006; Therrell et al., 2006; Brienen et al., 2010; Roozendaal and Zuidema, 2011). In comparison to repeated diameter measurements or permanently installed dendrometers, which yield reliable results only after several years of monitoring, dendrochronology allows an immediate estimation of C-sequestration (Schöngart et al., 2010) comprising the whole life span of a tree by retrospective analysis (Worbes, 2002).
Using a multiple regression model (Fig. 5) we predict tree age using $D$ and $\rho$ as independent parameters. Mean diameter increment correlates negatively with $\rho$, as is also known for tree species from the central Amazonian floodplain forests (Worbes et al., 1992; Schöngart, 2008; Schöngart et al., 2010). This can be explained by the percentage of wood anatomical features such as fiber length and fiber diameter, percentage of parenchyma and vessels as well as the incorporation of mineral salts and chemical substances in the heartwood such as terpenes, essential oils, tannins, flavonoids, aldheydes, alcohols, and colored pigments leading to different wood densities. Pioneer tree species generally have low fiber content and high vessel areas (Worbes, 1996) resulting in low wood densities, while climax tree species have high wood densities due to high fiber contents and thick cell walls with the incorporation of secondary substances and a relatively low vessel area. This relationship allows a reliable estimation of tree and stand ages for the monodominant forests formed by $V$. divergens covering a large proportion of Pantanal's landscape (Ariera et al., 2011) and is a powerful tool for future research and also for applications in conservation, 


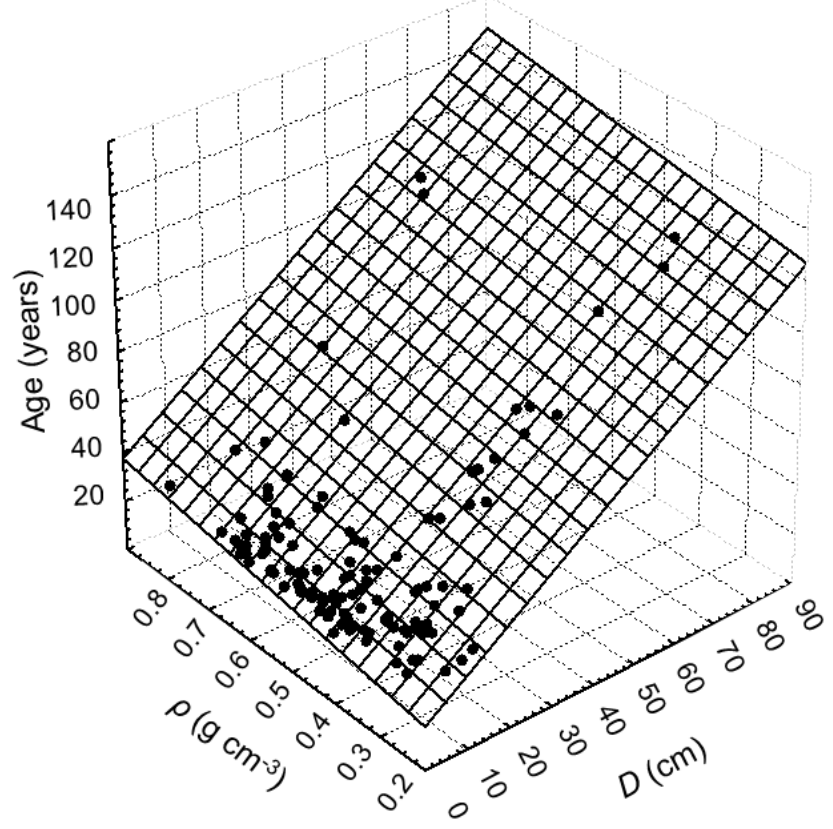

Fig. 5. Multiple regression model predicting tree age as a function of diameter, $D$, and wood density, $\rho$, developed by a data set of 117 trees of different successional stages of the wetland forests in the northern Pantanal $($ Age $=8.274+1.2153 \cdot D+28.405 \cdot \rho)$.

forest and landscape management. Such models can also be calibrated for other forest types in the Pantanal and other tropical regions.

In this study we perform an estimate of AGWB by allometric models developed on a pan-tropical database (Cannell, 1984; Chave et al., 2005). The results of the predicted AGWB (Table 3) indicate similar values within a forest stand, since both models use three independent parameters $(D, H, \rho)$. This suggests that allometric differences between models do play a less important role for the estimate of AGWB (Chave et al., 2005). Schöngart et al. (2010) compared seven different allometric equations using two and three independent parameters $(D, H$ and $\rho)$ in different combinations to transform inventory data into estimates of AGWB for different successional stages of central Amazonian floodplain forests. Equations (2) and (3) as well as another three-parameter model of Chave et al. (2005) also produced similar values of AGWB for the Amazonian floodplain forests. However, the tested models based on two parameters with different combinations (Brown et al., 1989; Malhi et al., 2004) yield considerably differing estimates of AGWB in comparison to those based on three parameters due to differences in the $H: D$ relationship and $\rho$ between the Amazonian floodplain tree species and the species used to calibrate the allometric models. A much higher uncertainty in the prediction of AGWB comes from the assumed measurement errors, especially from $\sigma_{\rho}$ and $\sigma_{H}$ in Eqs. (2) and (3). Such measurement errors are rarely propagated in studies es- timating AGWB (Chave et al., 2004). Tree height is rarely used to predict AGWB (Chave et al., 2004), but an important parameter as $H$ and thus the $H: D$ ratio varies considerably between forest types (Schöngart et al., 2010; Feldpausch et al., 2011). If an allometric model developed outside the biogeographic region that does not consider $H$ as predictor is applied to estimate AGWB, $H$ can become a major source of error, when the $H: D$ relationship between the original dataset differs considerably from that of the performed inventory. The same holds for wood density which can vary more than fivefold between tropical tree species (Chave et al., 2004; Schöngart et al., 2010). Huge databases comprising wood densities for hundreds of tropical tree species exist (e.g. Chave et al., 2009), yet for many tree species in the Pantanal region $\rho$ is still unknown.

In Table 6 we compare our estimates of C-stock and Csequestration in AGWB with data from a riparian forest in the southern Pantanal region (Wittmann et al., 2008), different successional stages from central Amazonian floodplain forests (Worbes, 1997; Schöngart et al., 2010), and dry forests from Mexico (Vargas et al., 2008). The estimated Cstocks in AGWB of the four studied stands are lower when compared to the estimated C-stocks in a flooded riparian forest along the Miranda River in the southern Brazilian Pantanal. This riparian forest studied by Wittmann et al. (2008) has 443 individuals $(D>10 \mathrm{~cm})$, a higher basal area of $47.8 \mathrm{~m}^{2} \mathrm{ha}^{-1}$ and the tree species present a higher mean $\rho$ $\left(0.63 \pm 0.12 \mathrm{~g} \mathrm{~cm}^{-3}\right)$ which results in a higher C-stock in AGWB which the authors predicted by using Eq. (2). The floodplain forests of central Amazonia also present higher values in the C-stocks of AGWB which can be traced back to higher tree densities, tree heights, and wood densities in the floodplain forests with similar stand age. C-sequestration in AGWB is also higher in the Amazonian floodplain forests which is a result of the high nutrient status of their alluvial soils (Schöngart et al., 2010). Seasonally tropical dry forests of Mexico indicate for the 99-yr and 108-yr old stands similar C-stocks to the wetland forests of the Pantanal, however, estimated C-sequestration in AGWB is lower in the dry forests compared to the wetland forest.

The use of geostatistical techniques to map wetland vegetation is a promising tool for conservation assessment and long-term ecological monitoring in wetlands also, because detailed biological information acquired in fieldwork can be integrated in the mapping procedure (Arieira et al., 2011). The distribution of C-stocks and tree age at stand scales indicate for stands 1-4 a spatial heterogeneity with older forest islands associated with higher C-stocks and younger patches with lower C-stocks (Fig. 6). These younger areas were probably occupied by $V$. divergens after consecutive severe droughts in the 1960s (Fig. 1) (Nunes da Cunha and Junk, 2004). The understanding of such dynamical processes is essential for the development of management concepts for the cultural landscapes and natural resources of this large wetland (timber, non-wood forest products). Traditional 
A

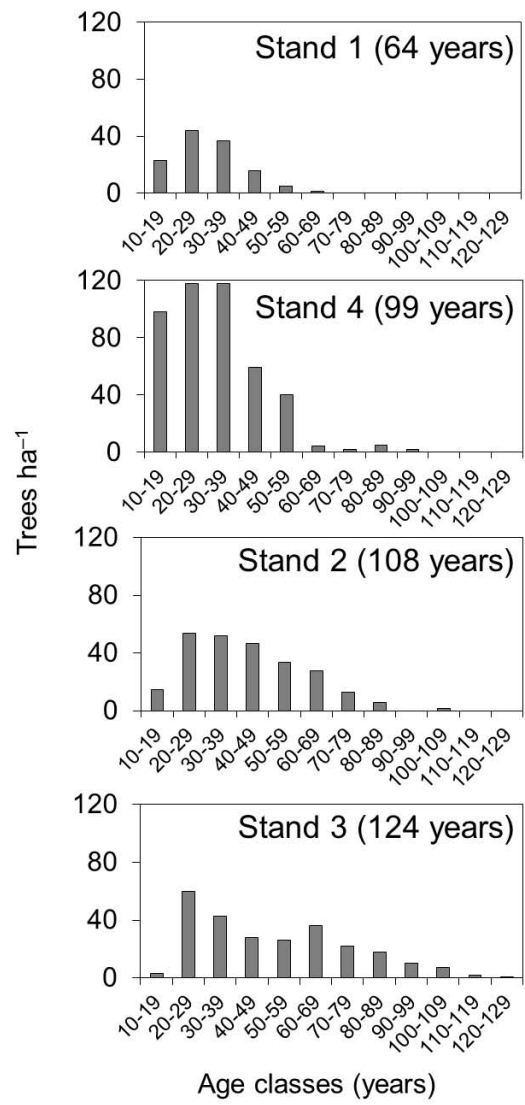

B

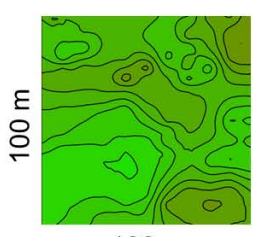

$100 \mathrm{~m}$

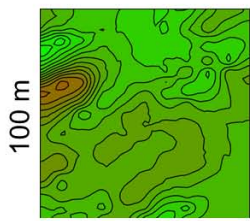

$100 \mathrm{~m}$

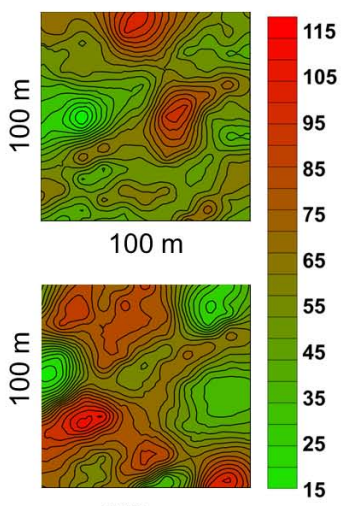

$100 \mathrm{~m}$
C

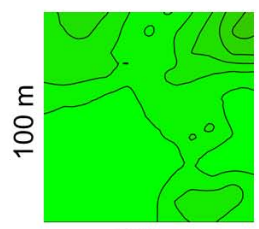

$100 \mathrm{~m}$

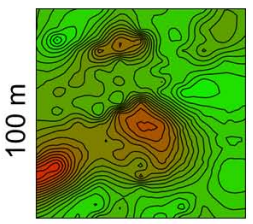

$100 \mathrm{~m}$

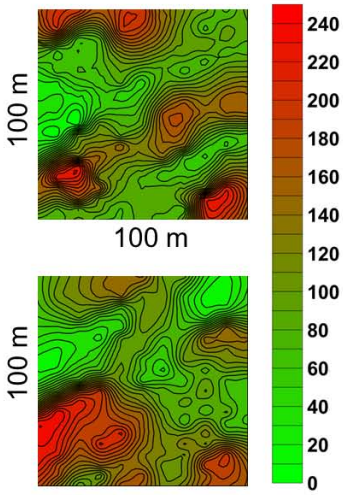

$100 \mathrm{~m}$

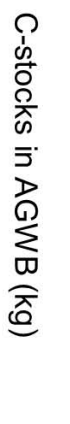

Fig. 6. (A) Age structure of the studied stands. Kriged maps indicate the spatial distribution of (B) tree age and (C) carbon stocks of the studied stands.

Table 5. Results of the variogram analysis: $\mathrm{Co}$ is the nugget effect, $\mathrm{Co}+\mathrm{C}$ is the sill representing the variance, $A$ is range of spatial dependence, and (Co.100)/C is the proportion of variance explained by random factors.

\begin{tabular}{|c|c|c|c|c|c|c|c|}
\hline Plot & Variable & Model & $\begin{array}{c}\text { Nugget } \\
\text { Co }\end{array}$ & $\begin{array}{c}\text { Sill } \\
\mathrm{Co}+\mathrm{C}\end{array}$ & $\begin{array}{c}\text { Range }(\mathrm{m}) \\
A\end{array}$ & $R^{2}$ & (Co.100)/C \\
\hline \multirow[t]{2}{*}{ Stand 1} & Age & Spherical & 1.595 & 3.468 & 85.2 & 0.98 & 45.99 \\
\hline & C-Stocks & Spherical & 840 & 15130 & 62.1 & 1 & 5.55 \\
\hline \multirow[t]{2}{*}{ Stand 2} & Age & Spherical & 12.5 & 233.2 & 32.8 & 1 & 5.36 \\
\hline & C-Stocks & Spherical & 100 & 265100 & 28.4 & 0.92 & 0.04 \\
\hline \multirow[t]{2}{*}{ Stand 3} & Age & Spherical & 64 & 458 & 32.5 & 0.99 & 13.97 \\
\hline & C-Stocks & Exponential & 77000 & 430000 & 59.1 & 0.99 & 17.91 \\
\hline \multirow[t]{2}{*}{ Stand 4} & Age & Spherical & 0.01 & 99.6 & 26.8 & 0.86 & 0.01 \\
\hline & C-Stocks & Spherical & 100 & 188600 & 37.3 & 0.97 & 0.05 \\
\hline
\end{tabular}

conflicts in the Pantanal between private stakeholders such as farmers and environmentalists require management plans. Extensive cattle ranching is the principle economic activity in the Pantanal. Farmers consider V. divergens and other tree species such as Byrsonima orbignyana (Malpighiaceae) and Curatella americana (Dilleneaceae) as invaders of their pastures (Santos et al., 2006). The dominating wet conditions during the last decades favored the progress of secondary 
Table 6. Comparison of C-storage, C-sequestration and C-turnover in AGWB of successional stages in wetland forests of the northern Pantanal and floodplain forests in the central Amazonia.

\begin{tabular}{lrr}
\hline Trees $(D \geq 10 \mathrm{~cm})$ & $\begin{array}{r}\mathrm{C}-\text {-stock } \\
\left(\mathrm{Mg} \mathrm{Cha}^{-1}\right)\end{array}$ & $\begin{array}{r}\text { C-sequestration } \\
\left(\mathrm{Mg} \mathrm{Cha}^{-1} \mathrm{yr}^{-1}\right)\end{array}$ \\
\hline Pantanal (This study) & & \\
\hline Stand 1 (stand age 64 yr) & $7.8 \pm 1.5$ & 0.5 \\
Stand 4 (stand age 99 yr) & $63.3 \pm 8.8$ & $3.3 \pm 0.3$ \\
Stand 2 (stand age 108 yr) & $97.2 \pm 14.4$ & $2.3 \pm 0.2$ \\
Stand 3 (stand age 124 yr) & $2.9 \pm 0.3$ \\
\hline Flooded riparian forest, Miranda River, southern Brazilian Pantanal & \\
\hline Wittmann et al. (2008) (unknown age) & $124.7^{1}$ & - \\
\hline Central Amazonian floodplain forests & & 7.2 \\
\hline Worbes (1997) (stand age 80 yr) & $140.0^{1}$ & 3.7 \\
Schöngart et al. (2010) (stand age 52 yr) & $117.4^{1}$ & \\
Schöngart et al. (2010) (stand age 125 yr) & $115.0^{1}$ & $1.2^{3}$ \\
\hline Seasonal dry forests, Mexico & & $1.0^{3}$ \\
\hline Vargas et al. (2008) (stand age 64 yr) & $58.6^{2}$ & $1.0^{3}$ \\
Vargas et al. (2008) (stand age 99 yr) & $65.1^{2}$ & $0.9^{3}$ \\
Vargas et al. (2008) (stand age 108 yr) & $65.9^{2}$ & $67.1^{2}$ \\
Vargas et al. (2008) (stand age 124 yr) & & \\
\hline
\end{tabular}

${ }^{1}$ AGWB estimated by Eq. (1), C-content estimated by $50 \%$ of AGWB.

${ }^{2}$ Calculated by a non-linear regression model (Richards Function) $\left(C\right.$-stock $\left.=69.1 \cdot(1-\exp (-0.027 \cdot \text { age }))^{0.84}\right)($ Vargas et al., 2008).

${ }^{3}$ Calculated by a non-linear regression model (C-sequestration $=-0.4414 \cdot \ln ($ age $\left.)+3.0449\right)($ Vargas et al., 2008).

succession invading pastures (Junk et al., 2006) and reduced considerably the area available for cattle, which is already limited by flooding. On the other hand, the secondary succession is of ecological value since these developing forests provide environmental services such as enhancing carbon stocks, habitat for a diverse fauna and flora, regulation of microclimate and hydrological cycles (Hasenack et al., 2003; Junk et al., 2006, 2011).

Dendroclimatological studies indicate for many tropical regions such as Indonesia (Jacoby and D'Arrigo, 1990), Namibia (Fichtler et al., 2004), Central Amazonia (Schöngart et al., 2004, 2005), West Africa (Schöngart et al., 2006), Zimbabwe (Therrell et al., 2006), and Mexico (Brienen et al., 2010) significant correlations between tree growth and ocean's SSTs, which trigger regional precipitation patterns and hydrological cycles in many areas of the tropics. Growth of V. divergens in the N-Pantanal responds to rainfall variability (Fortes, 2006). Positive SST anomalies in the El Niño $1+2$ region of the tropical Pacific basin $\left(0-10^{\circ} \mathrm{S}\right.$, $80-90^{\circ} \mathrm{W}$ ) cause significant lower rainfall in the Pantanal during the period October-December $(r=-0.39 ; p<0.01)$ resulting in reduced diameter increment rates (Fortes, 2006). If these drought episodes last for several years, as occurred during the 1960s (Fig. 1), forests of $V$. divergens die back (Nunes da Cunha and Junk, 2004), emitting large amounts of carbon from the AGWB to the atmosphere due to the high mortality rates. On the other hand, consecutive years of wet conditions favor the invasion of $V$. divergens into open areas and due to the higher increment rates (Fortes, 2006) more carbon is sequestered in the AGWB. However, future climate scenarios (IPCC, 2007) indicate increasing SSTs in the tropical oceans, which possibly will affect C-stocks in the AGWB of the wetland forests in the Pantanal, lowering Csequestration rates in the $V$. divergens dominated forests and increasing C-emission from the AGWB to the atmosphere. To what extent more drought resistant species will substitute $V$. divergens stands and compensate for the lower sequestration rates remains an open question.

\section{Conclusions}

Annual tree rings are widely distributed in the tropics and dendrochronology is a powerful methodology for a fast assessment of forest productivity at different stand ages and can be applied in different tropical forest ecosystems. Such information is of importance in the actual discussion of the function of tropical forests as $\mathrm{C}$-sinks in view of the ongoing global and regional climate change. The Pantanal wetland consists of different forest types as a consequence of varying 
edaphic, hydrologic and climatic conditions as well as landuse change (Ariera et al., 2011). More information on Cstocks, C-sequestration and climate growth relationships of the different forest types composed of drought resistant and flood tolerant tree species are necessary to give a better picture of the role of wetland forests in the carbon cycle of the Pantanal. To estimate the carbon balance in AGWB, it is also necessary to initiate the monitoring of wetland forests in permanent observation plots to obtain data on mortality and recruitment rates of important tree species and different forest types.

Acknowledgements. This study was financed by PELD (Programa de Pesquisa Ecológica de Longa Duração) supported by NEPA (Núcleo de Pesquisa Ecológica do Pantanal). We thank the SESC Reserve - RPPN for their support of the fieldwork and Wolfgang J. Junk for discussion. We acknowledge the valuable comments of Toby Marthews and an anonymous reviewer which substantially improved the quality of this study. We thank Tracey W. Andreae for improving the grammar and linguistic style of the manuscript.

The service charges for this open access publication have been covered by the Max Planck Society.

Edited by: A. Arneth

\section{References}

Arieira, J. and Nunes da Cunha, C.: Fitossociologia de uma floresta inundável monodominante de Vochysia divergens Pohl. (Vochysiaceae) no pantanal norte, MT, Brasil, Acta Bot. Bras., 20, 268-580, 2006.

Arieira, J., Karssenberg, D., de Jong, S. M., Addink, E. A., Couto, E. G., Nunes da Cunha, C., and Skøien, J. O.: Integrating field sampling, geostatistics and remote sensing to map wetland vegetation in the Pantanal, Brazil, Biogeosciences, 8, 667-686, doi:10.5194/bg-8-667-2011, 2011.

Arruda, E. C.: Composição florística, grupos ecológicos e características estruturais de clareiras em florestas inundáveis monodominantes de Vochysia divergens Pohl, no pantanal norte, Mato Grosso, M.Sc. thesis, Federal University of Mato Grosso, Brazil, 98 pp., 2006.

Baker, T. R., Phillips, O. L., Malhi, Y., Almeida, S., Arroyo, L., Di Fiore, A., Killeen, T. J., Laurance, S. G., Laurance, W. F., Lewis, S. L., Lloyd, J., Monteagudo, A., Neill, D. A., Patiño, S., Pitman, N. C. A., Silva, J. N. M., and Vásquez Martínez, R.: Variation in wood density determines spatial patterns in Amazonian forest biomass, Glob. Change Biol., 10, 545-562, 2004.

Brienen, R. J. W. and Zuidema, P. A.: Relating tree growth to rainfall in Bolivian rain forests: a test for six species using tree ring analysis, Oecologia, 146, 1-12, 2005.

Brienen, R. J. W., Lebrija-Trejos, E., Zuidema, P. A., and MartínezRamos, M.: Climate-growth analysis for a Mexican dry forest tree shows strong impact of sea surface temperatures and predicts future growth declines, Glob. Change Biol., 16, 2001-2012, 2010.
Brown, S., Gillespie, A. J. R., and Lugo, A. E.: Biomass estimation methods for tropical forests with applications to forestry inventory data, Forest Sci., 35, 881-902, 1989.

Cannell, M. G. R.: Woody biomass of forest stands, Forest Ecol. Manag., 8, 299-312, 1984.

Chambers, J. Q., Dos Santos, J., Ribeiro, R. J., and Higuchi, N.: Tree damage, allometric relationships, and above-ground net primary production in Central Amazon forest, Forest Ecol. Manag., 152, 73-84, 2001.

Chave, J., Condit, R., Aguilar, S., Hernandez, A., Lao, S., and Perez, R.: Error propagation and scaling for tropical forest biomass estimates, Phil. Trans. R. Soc. Lond. B, 359, 409-420, 2004.

Chave, J., Andalo, C., Brown, S., Cairns, M. A., Chambers, J. Q., Eamus, D., Fölster, H., Fromard, F., Higuchi, N., Kira, T., Lescure, J.-P., Nelson, B. W., Ogawa, H., Puig, H., Riéra, B., and Yamakura, T.: Tree allometry and improved estimation of carbon stocks and balance in tropical forests, Oecologia, 145, 8799, 2005.

Chave, J., Coomes, D., Jansen, S., Lewis, S. L., Swenson, N. G., and Zanne, A. E.: Towards a worldwide wood economics spectrum, Ecol. Lett., 12, 351-366, 2009.

Clark, D. A., Brown, S., Kicklighter, D. W., Chambers, J. Q., Thomlinson, J. R., Ni, J., and Holland E. A.: Net primary production in tropical forests: An evaluation and synthesis of existing field data, Ecol. Appl., 11, 371-384, 2001.

Drosg, M.: Dealing with Uncertainties - A Guide to Error Analysis, 2. edn., Springer, Dordrecht, Heidelberg, London, New York, 235 pp., 2009.

Elias, M. and Potvin, C.: Assessing inter- and intra-specific variation in trunk carbon concentration for 32 neotropical tree species, Can. J. For. Res., 33, 1039-1045, 2003.

Enquist, B. J. and Leffler, J.: Long-term tree ring chronologies from sympatric tropical dry-forest trees: individualistic responses to climatic variation, J. Trop. Ecol., 17, 41-60, 2001.

Fearnside, P. M.: Wood density for estimating forest biomass in Brazilian Amazonia, Forest Ecol. Manag., 90, 59-87, 1997.

Feldpausch, T. R., Banin, L., Phillips, O. L., Baker, T. R., Lewis, S. L., Quesada, C. A., Affum-Baffoe, K., Arets, E. J. M. M., Berry, N. J., Bird, M., Brondizio, E. S., de Camargo, P., Chave, J., Djagbletey, G., Domingues, T. F., Drescher, M., Fearnside, P. M., Frana, M. B., Fyllas, N. M., Lopez-Gonzalez, G., Hladik, A., Higuchi, N., Hunter, M. O., Iida, Y., Salim, K. A., Kassim, A. R., Keller, M., Kemp, J., King, D. A., Lovett, J. C., Marimon, B. S., Marimon-Junior, B. H., Lenza, E., Marshall, A. R., Metcalfe, D. J., Mitchard, E. T. A., Moran, E. F., Nelson, B. W., Nilus, R., Nogueira, E. M., Palace, M., Patiño, S., Peh, K. S.-H., Raventos, M. T., Reitsma, J. M., Saiz, G., Schrodt, F., Sonké, B., Taedoumg, H. E., Tan, S., White, L., Wöll, H., and Lloyd, J.: Height-diameter allometry of tropical forest trees, Biogeosciences, 8, 1081-1106, doi:10.5194/bg-8-1081-2011, 2011.

Fichtler, E., Trouet, V., Beeckman, H., Coppin, P., and Worbes, M.: Climatic signals in tree rings of Burkea africana and Pterocarpus angolensis from semiarid forests in Namibia, Trees-Struct. Funct., 18, 442-451, 2004.

Fortes, C. F.: Estudos dendrocronológicos da espécie arbórea Vochysia divergens Pohl (Vochysiaceae) no Pantanal Norte Matogrossense, Brasil, M.Sc. thesis, Federal University of Mato Grosso, Brazil, 24 pp., 2006. 
Fortunatti, C. M. and Couto, E. G.: A Diversidade dos solos no Pantanal Mato-Grossense, in: $56^{\mathrm{a}}$ Reunião Brasileira da SBPC, Cuiabá: SBPC, 18-23 July 2004.

Haase, R. and Hasse, P.: Aboveground biomass estimates for invasive trees and shrubs in the Pantanal of Mato-Grosso, Brazil, Forest Ecol. Manag., 73, 29-35, 1995.

Hasenack, H., Cordeiro, J. L. P., and Hofmann, G. S.: O clima da RPPN SESC Pantanal - Relatório técnico, Porto Alegre-UFRGS, Brazil, 31 pp., 2003.

Houghton, R. A., Skole, D. L., Nobre, C. A., Hackler J. L., Lawrence K. T., and Chomentowski, W. H.: Annual fluxes of carbon from deforestation and regrowth in the Brazilian Amazon, Nature, 403, 301-304, 2000.

IPCC: Climate Change 2007: The Physical Science Basis, Summary for Policymakers, Contribution of Working Group I to the Fourth Assessment Report of the Intergovernmental Panel on Climate Change (IPCC), WMO/UNEP, 18 pp., 2007.

Ishii, I. H.: Estudos dendrocronológicos e determinação de idade de árvores das matas ciliares do Pantanal Sul Mato-grossense, Ph.D. thesis, University of São Carlos-SP, Brazil, 140 pp., 1998.

Jacoby, G. C. and D'Arrigo, R. D.: Teak (Tectona grandis L.F.), a tropical species of large-scale dendroclimatic potential, Dendrocronologia, 8, 83-98, 1990.

Junk, W., Nunes da Cunha, C., Wantzen, K. M., Petermann, P., Strüssmann, C., Marques, M. I., and Adis, J.: Biodiversity and its conservation in the Pantanal of Mato Grosso, Brazil, Aquat. Sci., 68, 278-309, 2006.

Junk, W., Silva, C. J., Nunes da Cunha, C., and Wantzen, K. M.: The Pantanal: Ecology, biodiversity and sustainable management of a large tropical seasonal wetland, Pensoft Publishers, 857 pp., 2011.

Ketterings, Q. M., Coe, R., Van Noordwijk, M., Ambagau, Y., and Palm, C. A.: Reducing uncertainty in the use of allometric biomass equations for predicting above-ground biomass in mixed secondary forests, Forest Ecol. Manag., 146, 199-209, 2001.

Lloyd, J., Kolle, O., Fritsch, H., de Freitas, S. R., Silva Dias, M. A. F., Artaxo, P., Nobre, A. D., de Araújo, A. C., Kruijt, B., Sogacheva, L., Fisch, G., Thielmann, A., Kuhn, U., and Andreae, M. O.: An airborne regional carbon balance for Central Amazonia, Biogeosciences, 4, 759-768, doi:10.5194/bg-4-759-2007, 2007.

Lorenzi, H.: Árvores Brasileiras: Manual de Identificação e Cultivo de Plantas Arbóreas do Brasil, Ed. Nova Odessa, Brazil, 367 pp., 2002.

Loureiro, A. A., Da Silva, M. F., and Alencar, J. C.: Essências madeireiras da Amazônia, CNPq/INPA, Manaus, Brazil, 187 pp., 1979.

Malhi, Y., Baker, T. R., Phillips, O. L., Almeida, S., Alvarez, E., Arroyo, L., Chave, J., Czimczik, C. I., Di Fiore, A., Higuchi, N., Killeen, T. J., Laurance, S. G., Laurance, W. F., Lewis, L. L., Montoya, L. M. M., Monteagudo, A., Neill, D. A., Vargas, P. N., Patiño, S., Pitman, N. C. A., Quesada, C. A., Salomão, R., Silva, J. N. M., Lezama, A. T., Martínez, R. V., Terborgh, J., Vinceti, B., and Lloyd, J.: The above-ground coarse wood productivity of 104 Neotropical forest plots, Glob. Change Biol., 10, 563-591, 2004.

Mattos, P. P.: Identificação de anéis anuais de crescimento e estimativa de idade e incremento anual em diâmetro de espécies nativas do pantanal de Nhecolândia, M.Sc. thesis, Federal University of
Paraná, Brazil, 119 pp., 1999.

Miller, J., Franklin, J., and Aspinall, R.: Incorporating spatial dependence in predictive vegetation models, Ecol. Model., 202, 225-242, 2007.

Nogueira, E. M., Nelson, B. W., and Fearnside, P. M.: Wood density in dense forest in central Amazonia, Brazil, Forest Ecol. Manag., 208, 261-286, 2005.

Nunes da Cunha, C. and Junk, W. J.: Distribution of wood plant communities along the flood gradient in the Pantanal of Poconé, Mato Grosso, Brazil, Int. J. Ecol. Environ. Sci., 27, 63-70, 2001.

Nunes da Cunha, C. and Junk, W. J.: Year-to-year change in water level drive the invasion of Vochysia divergens in the pantanal grasslands, Appl. Veg. Sci., 7, 103-110, 2004.

Nunes da Cunha, C., Wantzen, K. M., and Junk, W. J.: The Pantanal Ecology Project: challenges and process of a Brazilian-German scientific collaboration, in: The Pantanal: Scientific and Institutional Challenges, in Management of a Large and Complex Wetland Ecosystem, Proceedings of the Symposium, 24th Annual Meeting of the Society of Wetlands Scientists, edited by: Tazik, D. J., Ioris, A. A. R., and Collinsworth, S. R., Washington, DC, USA, 56-77, 2004.

Ometto, J. P. H. B., Nobre, A. D., Rocha, H. R., Artaxo, P., and Martinelli, L. A.: Amazônia and the modern carbon cycle: lessons learned, Oecologia, 143, 483-500, 2005.

Peacock, J., Baker, T. R., Lewis, S. L., Lopez-Gonzalez, G., and Phillips, O. L.: The RAINFOR database: monitoring forest biomass and dynamics, J. Veg. Sci., 18, 535-542, 2007.

Pilcher, J. R.: Sample preparation, cross dating, and measurement, in: Methods of Dendrochronology, Applications in the Environmental Sciences, edited by: Cook, E. R. and Kairiukstis, L. A., Kluwer, Dordrecht, Boston, London, 40-51, 1990.

Pott, A.: Pastagens das sub-regiões dos Paiaguás e da Nhecolândia do Pantanal Mato-grossense, EMBRAPA-UEPAE de Corumbá, technical report, 10, Brazil, 49 pp., 1982.

Roozendaal, D. M. A. and Zuidema, P. A.: Dendroecology in the tropics: a review, Trees-Struct. Funct., 25, 3-16, 2011.

Salis, S. M., Assis, M. A., Mattos, P. P., and Pião, A. C. S.: Estimating the aboveground biomass and wood volume of savanna woodlands in Brazil's Pantanal wetlands based on allometric correlations, Forest Ecol. Manag., 228, 61-68, 2006.

Santos, S. A., Nunes da Cunha, C., Tomás, W., Abreu, U. G. P., and Arieira, J.: Plantas Invasoras no Pantanal: Como Entender o Problema e Soluções de Manejo por Meio de Diagnóstico Participativo, Boletim de Pesquisa e Desenvolvimento 66, Embrapa Pantanal, Corumbá, Brazil, 45 pp., 2006.

Schöngart, J.: Dendrochronologische Untersuchungen in Überschwemmungswäldern der Várzea Zentralamazoniens, Göttinger Beiträge zur Land- und Forstwirtschaft in den Tropen und Subtropen 149, Erich Goltze Verlag, 257 pp., 2003.

Schöngart, J.: Growth-Oriented Logging (GOL): a new concept towards sustainable forest management in Central Amazonian várzea floodplains, Forest Ecol. Manag., 256, 46-58, 2008.

Schöngart, J., Piedade, M. T. F., Ludwigshausen, S., Horna, V., and Worbes, M.: Phenology and stem-growth periodicity of tree species in Amazonian floodplain forests, J. Trop. Ecol., 18, 581597, 2002.

Schöngart, J., Junk, W. J., Piedade, M. T. F., Ayres, J. M., Hüttermann, A., and Worbes, M.: Teleconnection between Tree Growth in the Amazonian Floodplains and the El Niño-Southern 
Oscillation Effect, Glob. Change Biol., 10, 683-692, 2004.

Schöngart, J., Piedade, M. T. F., Wittmann, F., Junk, W. J., and Worbes, M.: Wood growth patterns of Macrolobium acaciifolium (Benth.) Benth. (Fabaceae), in: Amazonian black-water and white-water floodplain forests, Oecologia, 145, 454-461, 2005.

Schöngart, J., Orthmann, B., Hennenberg, K. J., Porembski, S., and Worbes, M.: Climate-growth relationships of tropical tree species in West Africa and their potential for climate reconstruction, Glob. Change Biol., 12, 1139-1150, 2006.

Schöngart, J., Wittmann, F., Worbes, M., Piedade, M. T. F., Krambeck, H.-J., and Junk, W. J.: Management criteria for Ficus insipida Willd. (Moraceae) in Amazonian white-water floodplain forests defined by tree-ring analysis, Ann. For. Sci., 64, 657-664, 2007.

Schöngart, J., Wittmann, F., and Worbes, M.: Biomass and NPP of Central Amazonian floodplain forests, in: Amazonian floodplain forests: Ecophysiology, biodiversity and sustainable management, edited by: Junk, W. J., Piedade, M. T. F., Wittmann, F., Schöngart, J., and Parolin, P., Ecological Studies, Springer Verlag, Dordrecht, Heidelberg, London, New York, 347-388, 2010.

Seidl, A. F., Silva, J. S. V., and Moraes, A. S.: Cattle ranching and deforestation in the Brazilian Pantanal, Ecol. Econ., 36, 413-425, 2001.

Silva, M. P., Mauro, R., Mourão, G., and Coutinho, M.: Conversion of forests and woodlands to cultivated pastures in the wetland of Brazil, Ecotropicos, 12, 101-108, 1999.

Stahle, D. W., Mushove, P. T., Cleaveland, M. K., Roig, F., and Haynes, G. A.: Management implication of annual growth rings in Pterocarpus angolensis from Zimbabwe, Forest Ecol. Manag., 124, 217-229, 1999.

Ter Steege, H.: Striving for a National Protected Areas System in Guyana, Flora of the Guianas Newsletter, 22, 65-66, 2001.

Therrell, M. D., Stahle, D. W., Ries, L. P., and Shugart, H. H.: Treering constructed rainfall variability in Zimbabwe, Clim. Dynam., 260, 677-685, 2006.
Vargas, R., Allen, M. F., and Allen, E. B.: Biomass and carbon accumulation in a fire chronosequence of a seasonally dry tropical, Glob. Change Biol., 14, 109-124, 2008.

Wagner, H. H. and Fortin, M.-J.: Spatial Analysis of Landscapes: Concepts and Statistics, Ecology, 86, 1975-1987, 2005.

Wittmann, F., Schöngart, J., Parolin, P., Worbes, M., Piedade, M. T. F., and Junk, W. J.: Wood specific gravity of trees in Amazonian white-water forests in relation to flooding, IAWA J., 27, 255266, 2006.

Wittmann, F., Zorzi, B. T., Tizianel, F. A. T., Urquiza, M. V. S., Faria, R. R., Sousa. N. M., Módena, E. S., Gamarra, R. M., and Rosa, A. L. M.: Tree species composition, structure, and aboveground wood biomass of a riparian forest of the lower Miranda River, Southern Pantanal, Brazil, Fol. Geobot., 43, 397411, 2008.

Worbes, M.: Rhythmisches Wachstum und anatomischmorphologische Anpassungen an Lebensstrategien von Bäumen in zentralamazonischen Überschwemmungswäldern, Mitt. Dtsch. Dendrol. Des., 82, 155-172, 1996.

Worbes, M.: The forest ecosystem of the floodplains, in: The Central Amazon Floodplains. Ecology of a Pulsing System, edited by: Junk, W. J., Springer-Verlag, USA, 223-266, 1997.

Worbes, M.: Annual growth rings, rainfall-dependent growth and long-term growth patterns of tropical trees from the Caparó Forest Reserve in Venezuela, J. Ecol., 87, 391-403, 1999.

Worbes, M.: One hundred years of tree-rings research in the tropics - a brief history and an outlook to future challenges, Dendrocronologia, 20, 217-231, 2002.

Worbes, M., Klinge, H., Revilla, J. D., and Martius, C.: On the dynamics, floristic subdivision and geographical distribution of várzea forests in Central Amazonia, J. Veg. Sci., 3, 553-564, 1992. 